Jan Piątkowski (1) https://orcid.org/0000-0001-5249-9024

Uniwersytet Mikołaja Kopernika w Toruniu

Beata Rutkowska (ㄱ) https://orcid.org/0000-0001-1920-8261

Uniwersytet Mikołaja Kopernika w Toruniu

\title{
DOPUSZCZALNOŚĆ UJAWNIANIA ZWIAZZKOM ZAWODOWYM INFORMACJI O WYSOKOŚCI WYNAGRODZENIA PRACOWNIKA W POWSZECHNYM MODELU ZATRUDNIENIA (ARTYKUŁ POLEMICZNY)*
}

\begin{abstract}
Admissibility of disclosing to trade unions information on the amount of an employee's remuneration in the common employment model (polemical article)

In doctrine and jurisprudence, the prevailing view is that employers are not obliged to disclose to trade unions, at their request and within the framework of trade union monitoring of compliance with the law, information on employee wages. According to the 1993 resolution of the panel of seven judges of the Supreme Court, an employer may disclose such information, but only with the employee's consent. Otherwise, the personal right of the person performing the work may be infringed. Such an opinion is not convincing. It stands in clear opposition to the law in force. It also leads to depriving the trade union organisation of the right to carry out systemic control of the employer's compliance with the principle of equal remuneration for equal work or work of equal value (Art. 18(3c) of the Labour Code).
\end{abstract}

* Opracowanie nie dotyczy osób, odnośnie do których - ze względu na potrzebę transparentności życia publicznego - informacja o wysokości wynagrodzenia pracownika jest informacją publiczną, a prawo do jej ujawnienia jest prawem obywatelskim. Chodzi w szczególności o osoby pełniące funkcje publiczne podlegające ustawie z dnia 6 września 2001 roku o dostępie do informacji publicznej (Dz.U. 2020, poz. 2176 tekst jedn.) oraz o kierowników podlegających ustawie z dnia 31 lipca 1981 roku o wynagrodzeniu osób zajmujących kierownicze stanowiska państwowe (Dz.U. 2020, poz. 1637 tekst jedn.), a także o osoby, do których odnosi się ustawa z dnia 3 marca 2000 roku o wynagradzaniu osób kierujących niektórymi podmiotami prawnymi (Dz.U. 2019, poz. 2136 tekst jedn.; zob. Safjan 2002, s. 10 i n.; Kamińska, Rozbicka-Kamińska 2012, s. 87 i n.). 
Słowa kluczowe: związek zawodowy, pracodawca, prawo do prywatności, pracownik, poufność wynagrodzenia, zasady wynagradzania, równe traktowanie pracowników, dobra osobiste, prawo rady zakładowej do informacji

Keywords: trade union, employer, right to privacy, employee, confidentiality of remuneration, rules of remuneration, equal treatment of employees, personal rights, works council's right to information

ASJC: 3308, JEL: K31

\section{Wprowadzenie do problematyki}

Jednym z czynników mających wpływ na kształt prawa pracy, a ściślej - na jego postrzeganie w skali kraju, jest działalność orzecznicza podejmowana przez Sąd Najwyższy (Piątkowski 2017, s. 66 i n.). Jest oczywiste, że Sąd Najwyższy nie jest podmiotem tworzącym prawo. Jest organem władzy sądowniczej powołanym między innymi do sprawowania wymiaru sprawiedliwości przez zapewnienie zgodności z prawem oraz jednolitości orzecznictwa sądów powszechnych i wojskowych. Praktyka dnia codziennego dostarcza wielu przykładów zmiany wykładni przepisów prawa w drodze podejmowania przez ten podmiot uchwał rozstrzygających zagadnienia prawne. Skutki takiej wykładni, zwłaszcza świadczącej o ukształtowanym kierunku judykatury, są zasadniczo podobne do skutków wynikających z uchwalenia nowego prawa - z tym zastrzeżeniem, że od strony formalnej taka wykładnia co do zasady ${ }^{1}$ nie ma mocy wiążącej dla podmiotów stosujących prawo. Wymownym tego przykładem jest uchwała pełnego składu Izby Administracyjnej, Pracy i Ubezpieczeń Społecznych z dnia 11 marca 1993 roku (I PZP 68/92, OSNC 1993, nr 9, poz. 140), w której na nowo ukształtowano przesłanki ochrony pracownika przed wypowiedzeniem umowy o pracę w okresie choroby, chociaż art. 41 ustawy z dnia 26 czerwca 1974 roku - Kodeks pracy (Dz.U. 2020, poz. 1320 tekst jedn., dalej: „Kodeks pracy”, „k.p.”) zachował swą dotychczasową treść 2 Z tego samego okresu pochodzi uchwała składu siedmiu sędziów Sądu Najwyższego z dnia 16 lipca 1993 roku (I PZP 28/93, OSNC 1994, nr 1, poz. 2, dalej: „uchwała z 1993 roku”)’3, która ukształtowała i ujednoliciła wykładnię przepisów dotyczących dopuszczalności ujawniania związkom zawodowym informacji o wysokości wynagrodzenia za pracę.

Problematyka udostępniania związkom zawodowym informacji o wysokości wynagrodzeń pracowników w powszechnym modelu zatrudnienia należy do zagadnień o dużym ładunku wrażliwości społecznej, na co jednoznacznie wskazują wieloletnie doświadczenia autorów niniejszego opracowania związane z praktyką ekspercką. Z jednej strony zagadnieniem tym interesują się przedstawiciele związków zawodowych z racji

1 Wykładnia Sądu Najwyższego ma moc wiążącą dla sądu, który skierował do tego podmiotu zapytanie prawne.

2 Jedyną zmianą tego przepisu była zmiana terminologiczna - w miejsce zakładu pracy pojawił się pracodawca.

3 W tym kierunku wypowiadają się też inne sądy (zob. wyrok Sądu Apelacyjnego w Białymstoku z 25 czerwca 2014 roku, III AUa 2078/13, LEX nr 1493722). 
swoich kompetencji, a z drugiej - sami pracownicy. Ci pierwsi szukają odpowiedzi na pytanie, dlaczego wiedzę o wysokości wynagrodzeń może posiadać w zakładzie pracy wiele osób (między innymi przedstawiciele działów płacowych czy kadrowych), tylko nie działacze związku zawodowego, choć jednych i drugich obowiązuje zakaz ujawniania posiadanych informacji. Wrażliwość społeczna po stronie samych pracowników wiąże się zaś z problematyką dóbr osobistych. W orzeczeniu z dnia 26 kwietnia 2018 roku (Dz.U. 2018, poz. 830) Trybunał Konstytucyjny wskazał, że kwestia udostępniania danych osobowych związkom zawodowym rodzi praktyczne problemy, wynikające z konkurencji dwóch wartości konstytucyjnych, jakimi są z jednej strony wolność związkowa i wynikające z niej prawo związków zawodowych do informacji, a z drugiej strony - prawo pracownika do ochrony jego prywatności. Konflikt dwóch tak istotnych wolności i praw dostrzeżono również w doktrynie. Wyrażono tam zapatrywanie, że wspomniane prawo pracownika do prywatności zderza się z koniecznością zabezpieczenia owej prywatności przed prasą i związkami zawodowymi, które powołując się na własne wolności, żądają informacji na temat pracowników (Gersdorf 2014).

W uchwale z 1993 roku Sąd Najwyższy dostrzegł prawo związku zawodowego do kontroli wysokości wynagrodzeń konkretnych pracowników. Uznawszy brak obowiązku pracodawcy ujawniania związkom zawodowym informacji o wysokości wynagrodzenia pracownika (dalej: „obowiązek informacyjny”), przyjął jednak, że ujawnienie takiej informacji bez zgody pracownika mogłoby doprowadzić do naruszenia jego dóbr osobistych. W nauce prawa już od dawna prezentowany jest pogląd, że wysokość wynagrodzenia pracowniczego stanowi sferę prywatności, której bezprawne naruszenie może stanowić naruszenie dobra osobistego (Szewczyk 2007, s. 388 i n.; Cudowski 2013, s. 71). Sąd Najwyższy wyraził też zapatrywanie, że pozyskanie informacji o wysokości wynagrodzenia pracownika nie jest niezbędne do prowadzenia działalności związkowej.

Teza Sądu Najwyższego i uzasadnienie uchwały z 1993 roku są niemalże powszechnie akceptowane w doktrynie (Niezbecka 1992, s. 71; Baran 2010, s. 264; Drozd 2012; Kulesza 2017, s. 181-182) 4 i orzecznictwie (wyrok Trybunału Konstytucyjnego z dnia 26 kwietnia 2018 roku, K 6/15, Dz.U. 2018, poz. 830)5 , co niestety znajduje odzwierciedlenie w obrocie prawnym. Tylko w przypadku wypowiedzenia zmieniającego Sąd Najwyższy dostrzega obowiązek ujawnienia związkom zawodowym wysokości nowego wynagrodzenia bez zgody pracownika (wyrok z dnia 24 października 2012 roku, I PK 151/12, OSNP 2013, nr 17-18, poz. 205). Można odnieść wrażenie, że w kwestii braku obowiązku ujawniania związkom zawodowym informacji o wysokości wynagrodzenia pracownika mamy do czynienia z ujednoliconym i utrwalonym poglądem, zarówno w doktrynie, jak i w judykaturze, i że za sprawą uchwały z 1993 roku wszelkie kwestie związane z tym tematem zostały rozstrzygnięte (Derlacz-Wawrowska 2013,

4 Niektórzy przedstawiciele doktryny wyrażają odmienny pogląd (Włodarczyk 2001, s. 63-64; Piątkowski 2008, s. 254-255).

5 Orzeczenie to dotyczy autonomii informacyjnej pracownika w kontekście realizacji funkcji kontrolnej przez społecznych inspektorów pracy. 
s. 378 i n.; Kulesza 2017, s. 18). Świadczyć o tym może również zdecydowanie mniejsza aktywność przedstawicieli nauki prawa w podejmowaniu tego tematu. Czy jednak rzeczywiście można uznać, że rozważana kwestia przestała być istotnym problemem badawczym i nie powinna stanowić przedmiotu większego zainteresowania nauki prawa? Można mieć w tym zakresie poważne wątpliwości.

\section{Kontrowersje wokół uchwały Sądu Najwyższego z 1993 roku}

Stanowisko Sądu Najwyższego wyrażone w uchwale z 1993 roku, a zwłaszcza w jej uzasadnieniu, budzi poważne zastrzeżenia nie tylko w kontekście przepisów ustawy z dnia 23 maja 1991 roku o związkach zawodowych (Dz.U. 2019, poz. 263 tekst jedn., dalej: „ustawa o związkach zawodowych”, „u.z.z."), które w omawianym zakresie nie uległy od 1993 roku istotnym zmianom, ale także przez wzgląd na realizację podstawowej zasady równego wynagradzania pracowników za jednakową pracę lub za pracę o jednakowej wartości (art. 183c k.p.). Przyjęcie takiego poglądu prowadzi w praktyce do pozbawienia pracowników systemowej kontroli przestrzegania przez pracodawcę wskazanej wyżej podstawowej zasady prawa pracy, która została wprowadzona do Kodeksu pracy już po podjęciu przez Sąd Najwyższy uchwały z 1993 roku.

Zasadnicza wątpliwość co do poglądu o braku obowiązku informowania związku zawodowego (na jego wniosek) o wysokości wynagrodzenia za pracę konkretnego pracownika dotyczy naruszenia przez Sąd Najwyższy konwencji normatywnej art. 28 u.z.z., którego konstrukcja prawna została zachowana także w jego obecnym brzmieniu (Baran 2019). Przepis ten zawiera ogólną formułę informacji niezbędnych do prowadzenia działalności związkowej. Zawarte tam wyliczenie rodzaju „niezbędnych informacji” nie ma charakteru zamkniętego. Ustawodawca wskazuje jedynie szczególne przypadki zakresu odniesienia przyjętej w tym przepisie ogólnej konwencji, co wynika z zawartego tam zwrotu „w szczególności”. Przykładowe wyliczenie w art. 28 „niezbędnych informacji” jest pozbawione przymiotu zupełności (Baran 2010, s. 263; Wujczyk 2019, s. 208), co oznacza, że przepis ten nie może stanowić podstawy do „blokowania” innych informacji niezbędnych do prowadzenia działalności związkowej ${ }^{6}$. Za takim stanowiskiem przemawiają również zasady techniki prawodawczej. Jedna z nich zakłada ${ }^{7}$, że jeżeli nie jest możliwe sformułowanie całego zakresu odniesienia przepisu, można objaśnić jego znaczenie przez przykładowe wyliczenie jego zakresu, wyraźnie wskazując przykładowy charakter wyliczenia przez posłużenie się takimi zwrotami jak „w szczególności” czy „a zwłaszcza”. Przeciwko poglądowi Sądu Najwyższego przemawia również wynikająca z teorii prawa dyrektywa interpretacyjna drugiego stopnia oraz zasada pewności prawa

6 Tak też rozumie zwrot „w szczególności” Naczelny Sąd Administracjny w kwestii dotyczącej ważnych powodów wydawania pozwolenia na broń (wyrok z dnia 2 grudnia 2015, II OSK 847/14, LEX nr 2000035).

7 Zob. $\$ 153$ rozporządzenia Prezesa Rady Ministrów z dnia 20 czerwca 2002 roku w sprawie Zasad Techniki Prawodawczej, Dz.U. 2016, poz. 283 tekst jedn. 
(zasada przewidywalności konsekwencji prawnych). Stanowisko Sądu Najwyższego jest też zaprzeczeniem zasady, że jeśli norma zawarta w konkretnym przepisie (w tym wypadku w art. 28 u.z.z.) ma ogólną treść (za sprawą ogólnej formuły zawartej $\mathrm{w}$ tym przepisie), to nie powinna ona być interpretowana zawężająco. W doktrynie zostało też wyrażone stanowisko, że skoro przepisy ustawy o związkach zawodowych nie zawierają wyraźnego zakazu udzielania związkom zawodowym informacji o wysokości wynagrodzenia konkretnego pracownika bez jego przyzwolenia, to pozwala to rozważać dopuszczalność takiego działania przez pracodawcę (Włodarczyk 2012, s. 155 i n.).

Wątpliwości co do braku obowiązku informacyjnego wiążą się również z ograniczonym zakresem rozważań prowadzonych przez Sąd Najwyższy. Pogląd o braku obowiązku informacyjnego Sąd Najwyższy wywodzi wyłącznie z art. 28. Nie analizował tego zagadnienia w szerszym kontekście, co do zasady utrwalonym w doktrynie (Derlacz-Wawrowska 2015, s. 92-93), to jest nie wziął pod uwagę art. 23 (obecnie art. 26), w którym ustawodawca jednoznacznie przyznaje związkom zawodowym uprawnienie do kontroli przestrzegania prawa przez pracodawcę i podkreśla to zwrotem „w szczególności”. Takie uprawnienie wynika również z art. 8 u.z.z. Skoro więc zdaniem Sądu Najwyższego udostępnianie informacji o wynagrodzeniu pracownika mieści się w uprawnieniach kontrolnych związku zawodowego, to bez wątpienia właśnie tu (w art. 23, obecnie art. 26, a nie w art. 28 u.z.z.) należy poszukiwać odpowiedzi na pytanie, czy pozyskanie informacji jest niezbędne do prowadzenia działalności związkowej ${ }^{8}$. Sąd Najwyższy wyraźnie wskazuje, że przepis ten obejmuje uprawnienie związku do kontrolowania wysokości wynagrodzenia pracownika, jednak bez jakiegokolwiek uzasadnienia nie widzi w nim podstawy do przyjęcia obowiązku informacyjnego. Co więcej, wiąże takie uprawnienie z przesłanką nieprzewidzianą w art. 26 u.z.z., to jest ze zgodą pracownika, co oznacza nadinterpretację tego przepisu i sprzeniewierzenie się woli ustawodawcy. Sąd Najwyższy jest przy tym niekonsekwentny, albowiem za niezbędne informacje uważa jedynie informacje o wysokości wynagrodzenia, gdy „interesy konkretnego pracownika są zagrożone w zakresie kształtowania jego wynagrodzenia za pracę i zwróci się on do związku zawodowego o zbadanie tej kwestii lub wyrazi na to zgodę" (Drozd 2012, s. 402). Nie przeszkodziło to Sądowi Najwyższemu uznać, że informacja o zasadach wynagradzania jest wystarczająca do ochrony interesów indywidualnych pracownika. Istotne przy tym jest także to, że zdaniem Sądu Najwyższego ujawnienie wysokości wynagrodzenia bez zgody pracownika może (a więc nie musi) skutkować naruszeniem jego dobra osobistego ${ }^{9}$. Czy w sytuacji, gdy nie dochodzi do naruszenia dobra osobistego, nadal mamy do czynienia z uprawnieniem pracodawcy, a nie z obowiązkiem informacyjnym?

8 W doktrynie podkreśla się, że otrzymanie od pracodawcy informacji niezbędnych do prowadzenia działalności związkowej jest dążeniem do osiągnięcia właściwej racjonalności i efektywności związkowego działania (Włodarczyk 2014, s. 438-439).

9 Ujawnienie przez pracodawcę informacji o wysokości wynagrodzenia pracownika będzie równoznaczne z naruszeniem dobra osobistego, gdy taką informację będzie można zaliczyć do „sfery prywatności” pracownika (Książek 2019, s. 121). 
Objęcie przez Sąd Najwyższy kontrolą związkową wysokości wynagrodzeń pracowników ma istotne znaczenie dla postrzegania charakteru takiej kontroli jako niezależnej od zgody pracownika na ujawnienie informacji o wysokości jego wynagrodzenia za pracę. W wyroku z dnia 26 kwietnia 2018 roku Trybunał Konstytucyjny uznał uprawnienia kontrolne $\mathrm{z}$ ustawy o związkach zawodowych nie tylko za instrument ochrony pracowników, ale także za instrument konstytucyjnego nadzoru państwa nad warunkami pracy (art. 24 Konstytucji RP). Wskazał jednocześnie, że taki instrument powinien być skuteczny. Skoro kontrola związkowa jest instrumentem realizacji przez państwo funkcji publicznej, to taka kontrola w istocie jest kontrolą publiczną, sprawowaną za pośrednictwem związku zawodowego. Uzależnienie jej od zgody pracownika byłoby zaprzeczeniem istoty takiej kontroli, zwłaszcza że brak zgody pracownika można wymusić klauzulą poufności wynagradzania lub klimatem zastraszenia pracowników, na co wskazuje praktyka dnia codziennego.

Kolejne zastrzeżenie do stanowiska Sądu Najwyższego wyrażonego w uchwale z 1993 roku dotyczy zaskakującego sposobu rozumienia sformułowania „zasady wynagradzania” zawartego w art. 28 u.z.z. ${ }^{10}$ Sąd Najwyższy bez bliższego uzasadnienia przyjął, niejako $\mathrm{z}$ założenia, że powyższy zwrot uzupełnia zawartą $\mathrm{w}$ tym przepisie formułę „w szczególności" w ten sposób, że ją konkretyzuje w obszarze wynagradzania za pracę, a przez to eliminuje informacje o wysokości wynagrodzenia pracownika z katalogu informacji niezbędnych do prowadzenia działalności związkowej. Takie zapatrywanie jest nieuprawnione. Po raz kolejny w wyraźny sposób narusza przyjętą przez ustawodawcę w art. 28 konwencję zakreśloną zwrotem „w szczególności”, którego znaczenie w nauce prawa wydaje się utrwalone. Sąd Najwyższy wyszedł z założenia, że informacja o zasadach wynagradzania jest wystarczająca do ochrony nie tylko interesów grupowych, ale i interesów indywidualnych, co wydaje się tezą nieuprawnioną, zwłaszcza w kontekście związkowej kontroli przestrzegania przez pracodawcę zasady równego wynagradzania za pracę (art. $18^{3 \mathrm{c}}$ k.p.), która dla swej skuteczności musi opierać się na informacji o wysokości wynagrodzeń pracowników i ich porównywalności. To po raz kolejny dowodzi naruszenia przez Sąd Najwyższy konwencji art. 28 u.z.z. Nie ma w twierdzeniu Sądu Najwyższego logicznej poprawności ani przyczynowo-skutkowego stosunku wynikania. Zasady wynagradzania (jako kategoria ogólna, ponadindywidualna) i wynagrodzenie konkretnego pracownika (jako kategoria indywidualna) to dwa różne terminy prawne (a nie prawnicze), którym ustawodawca nadaje różną treść. Nie ma żadnych podstaw prawnych, aby stosunek wzajemnej zależności między tymi terminami postrzegać w sposób przyjęty przez Sąd Najwyższy w uchwale z 1993 roku.

Pogląd o istnieniu (de lege lata) obowiązku informacyjnego daje się uzasadnić nie tylko $\mathrm{w}$ wymiarze prawnym, ale również $\mathrm{w}$ aspekcie aksjologicznym. Uzależnienie ujawnienia związkom zawodowym informacji o wysokości wynagrodzenia od zgody

10 W praktyce zakładowej pracodawcy niejednokrotnie odmawiają związkom zawodowym ujawniania informacji o zasadach wynagradzania, powołując się na przepisy o ochronie danych osobowych (Kulesza 2017, s. 182). 
pracownika kłóci się z wartością nadrzędną, jaką jest prawo wszystkich pracowników do jednakowego wynagradzania za jednakową pracę lub za pracę o jednakowej wartości. Powinność równego traktowania pracowników w zakresie wynagradzania za pracę jest wartością dominującą i nadrzędną nad prawem indywidualnego pracownika do poufności jego wynagrodzenia. Przemawia za tym nie tylko interes społeczny, ale również właściwie rozumiany interes każdego pracownika.

\section{Konflikt trzech wartości}

Uznanie istnienia po stronie pracodawcy obowiązku informacyjnego (który zdaje się wynikać z obowiązujących przepisów prawa) zapewni korelację przepisów mających za przedmiot ujawnianie informacji o wysokości wynagrodzeń pracowników z przepisami dotyczącymi podstawowej zasady jednakowego wynagradzania za jednakową pracę lub pracę o jednakowej wartości. Spojrzenie na omawiane zagadnienie z tej ogólniejszej perspektywy, to jest przez pryzmat art. 183c k.p., pozwoli na ukazanie roli związku zawodowego w kontroli przestrzegania przez pracodawcę tej jednej z podstawowych zasad prawa pracy - kontroli mającej charakter systemowy, a więc przeprowadzanej niejako „Z urzędu” i niezależnej od zgody pracownika. Zasadniczym celem takiej kontroli jest ochrona ogółu pracowników zakładu przed niewłaściwą polityką pracodawcy w zakresie równego wynagradzania za pracę. W ten sposób jest zaspakajany nie tylko indywidualny interes każdego pracownika, ale przede wszystkim interes państwa, wyrażający się w potrzebie poszanowania prawa.

To oznacza zarazem, że problematyka dopuszczalności ujawniania związkom zawodowym informacji o wysokości wynagrodzenia za pracę odnosi się już nie tylko do dwóch wartości prawnie chronionych (prawo pracownika do prywatności i prawo związku zawodowego do informacji), które mogą pozostawać we wzajemnym konflikcie (była o tym mowa we wcześniejszych rozważaniach), ale także do trzeciej wartości, to jest do potrzeby równego traktowania pracowników w zakresie wynagradzania za jednakową pracę lub za pracę o jednakowej wartości. Ten obszar badawczy jest w nauce prawa słabiej zagospodarowany, a sporadyczne rozważania w tym zakresie są prowadzone zasadniczo w nieco innym odniesieniu (Walczak 2015, s. 257; 2017, s. 287-288) ${ }^{11}$.

Jest oczywiste, że związkowa kontrola przestrzegania przez pracodawcę przepisów prawa pracy obejmuje również kontrolę przestrzegania przepisów dotyczących równego wynagradzania pracowników za jednakową pracę lub pracę o jednakowej wartości. Taka kontrola, jak wcześniej wspomniano, opiera się na wiedzy o zarobkach pracowników i porównywalności tych zarobków. Do uzyskania wiedzy w tym zakresie i możliwości

11 Autor opowiada się za odrzuceniem całkowitego zakazu ujawniania przez pracownika informacji na temat jego własnego wynagrodzenia $\mathrm{z}$ uwagi na przepisy dotyczące niedyskryminacji. Aby przeciwdziałać nieuzasadnionym praktykom w tym zakresie, musi istnieć konieczność chociażby minimalnej wiedzy na temat zasad przyznawania poszczególnych składników wynagrodzenia oraz ich wysokości. 
porównywania zarobków pracowników nie wystarczy udostępnienie związkom zawodowym informacji o zasadach wynagradzania. Taka kontrola, o czym także była już mowa, realizuje funkcję publiczną państwa, a więc nie może być uzależniona od zgody pracownika na ujawnienie wysokości jego wynagrodzenia, tym bardziej że ustawa o związkach zawodowych nie łączy związkowej kontroli z takim ograniczeniem.

Mając powyższe na uwadze, trzeba stwierdzić, że przepisy dotyczące obowiązku informacyjnego stanowilyby instrument kontroli przestrzegania przez pracodawcę jednej z podstawowych zasad prawa pracy. W sytuacji pozyskania przez związek zawodowy informacji o nierównym traktowaniu pracowników w zakresie wynagradzania za pracę mógłby on przekazać informację o tym Państwowej Inspekcji Pracy. Organizacja związkowa, w przeciwieństwie do kontroli państwowej, jest bowiem w tym zakresie pozbawiona realnych środków pokontrolnych i nadzorczych. W ten sposób realizowałaby się idea i powinność współdziałania związku zawodowego i Państwowej Inspekcji Pracy, do których odwołuje się ustawodawca w art. 14 ust. 1 ustawy z dnia 13 kwietnia 2007 roku o Państwowej Inspekcji Pracy (Dz.U. 2019, poz. 1251 tekst jedn.) oraz w art. 26 pkt 4 u.z.z.

Ujawnianie związkom zawodowym informacji o wysokości wynagrodzenia bez zgody pracownika nie narusza przepisów RODO, to jest Rozporządzenia Parlamentu Europejskiego i Rady (UE) 2016/679 z dnia 27 kwietnia 2016 roku w sprawie ochrony osób fizycznych w związku z przetwarzaniem danych osobowych i w sprawie swobodnego przepływu takich danych oraz uchylenia dyrektywy 95/46/WE (ogólne rozporządzenie o ochronie danych, Dz.Urz. UE L 2016, nr 119/1). Takie działanie ma bowiem wyraźną podstawę prawną (art. 6 ust. 1 lit. c RODO), gdyż w zakresie, w jakim przetwarzanie danych jest niezbędne do wypełnienia obowiązku prawnego ciążącego na administratorze, zgoda pracownika jest prawnie obojętna. Polska ustawa z dnia 10 maja 2018 roku o ochronie danych osobowych (Dz.U. 2019, poz. 1781 tekst jedn.) nie wprowadziła w tym obszarze szczególnej regulacji. Takie działanie pracodawcy nie uruchamia też ochrony na podstawie przepisów o ochronie dóbr osobistych, skoro nie można przypisać mu cechy bezprawności.

\section{Niemiecka droga do kompromisu ${ }^{12}$}

Problem udostępniania przedstawicielstwu pracowniczemu informacji dotyczących wynagrodzenia za pracę konkretnych pracowników i jego zgodności z RODO nie jest typowy tylko dla Polski. Zagadnienie to jest analizowane również w innych państwach, na przykład na gruncie niemieckiego prawa pracy. W Niemczech problem ten dotyczy wprawdzie nie związku zawodowego, lecz rady zakładowej (Betriebsrat), która stanowi

12 Ta część opracowania została oparta na orzecznictwie i literaturze zgromadzonych w trakcie pobytu badawczego w Zentrum für Arbeitsbeziehungen und Arbeitsrecht (ZAAR) w Monachium, sfinansowanego ze stypendium DAAD. 
zakładowe przedstawicielstwo pozazwiązkowe i ma inną pozycję prawną niż polska zakładowa organizacja związkowa, niemniej jednak istota problemu jest taka sama.

Radzie zakładowej przysługuje bardzo szeroki zakres uprawnień o zróżnicowanym charakterze. Ich wykonywanie wymaga niejednokrotnie dostępu do określonych informacji. Prawo do informacji rady zakładowej jest - podobnie jak w Polsce analogiczne prawo związku zawodowego - ujęte w dwojaki sposób. Z jednej strony rada korzysta ze szczegółowych uprawnień informacyjnych w ramach realizacji konkretnych praw dotyczących na przykład spraw personalnych (Junker 2019, s. 382). Z drugiej strony przysługuje jej prawo do informacji wynikające z ogólnego obowiązku współpracy w duchu zaufania, jaki spoczywa na pracodawcy (Junker 2019, s. 381). Prawo to uregulowane jest w $\$ 80$ ust. 2 ustawy o ustroju zakładu pracy (Betriebsverfassungsgesetz, dalej: „BetrVG”). Zgodnie z tym przepisem w celu wykonywania obowiązków wynikających z ustawy rada zakładowa ma być wyczerpująco i we właściwym terminie informowana przez pracodawcę, przy czym informowanie to rozciąga się również na zatrudnienie osób, które nie pozostają z pracodawcą w stosunku pracy, i obejmuje w szczególności czasowy zakres zatrudnienia, miejsce zatrudnienia i zadania zawodowe tych osób.

Inaczej niż w przypadku art. 28 u.z.z. $\$ 80$ ust. 2 BetrVG odnosi się wyraźnie do udostępniania radzie zakładowej dokumentów, w tym list wynagrodzeń brutto. Przepis ten stanowi, że radzie zakładowej udostępnia się w każdej chwili, na jej wniosek, dokumenty niezbędne do wykonywania jej obowiązków i że w tych ramach komitet zakładowy (tworzony przez radę zakładową składającą się z dziewięciu lub więcej członków do prowadzenia bieżących spraw rady) lub komitet utworzony zgodnie z $\$ 28$ BetrVG (organ, który rada zakładowa może utworzyć w zakładzie z ponad stu pracownikami w celu przekazania mu określonych zadań; składa się tylko z członków rady zakładowej) ma prawo wglądu w wykazy wynagrodzeń brutto. Udostępniane listy płac brutto powinny zawierać informacje dotyczące wszystkich składników wynagrodzenia, niezależnie od tego, czy są to świadczenia jednorazowe, czy powtarzalne, ani na jakiej podstawie są oparte (Hromadka, Maschmann 2017, s. 373; Fitting 2020, \$80 BetrVG, nr 73).

Jak wynika z przytoczonej regulacji, $\$ 80$ ust. 2 BetrVG nie przesądza wprost, czy listy płac brutto, do których wglądu ma prawo komitet zakładowy lub komitet utworzony zgodnie z $\$ 28$ BetrVG, mogą zawierać dane osobowe poszczególnych pracowników (na przykład ich imiona, nazwiska, wiek, numery identyfikacyjne itp.). Pojawia się w tym kontekście pytanie o zgodność udostępniania radzie zakładowej wykazów wynagrodzeń brutto zawierających dane osobowe pracowników z RODO ${ }^{13}$.

Problem ten znalazł odzwierciedlenie w orzecznictwie niemieckich sądów pracy. Tytułem przykładu można wskazać orzeczenia: sądu pracy Landu Meklemburgia Pomorze Przednie (Landesarbeitsgericht Mecklenburg-Vorpommern) z 15 maja 2019 roku

13 Prawo wglądu przedstawicielstwa pracowniczego w wykazy wynagrodzeń brutto $\mathrm{z}$ danymi osobowymi pracowników jest analizowane w niemieckiej judykaturze i literaturze przedmiotu także z perspektywy konstytucji i ustawy o przejrzystości wynagrodzeń (Entgelttransparenzgesetz). Wątki te zostały pominięte w niniejszym opracowaniu. 
(3 TaBV 10/18), sądu pracy Landu Saksonii-Anhalt (Landesarbeitsgericht Sachsen-Anhalt) z 18 grudnia 2018 roku (4 TaBV 19/17, NZA-RR 2019, 256) czy Federalnego Sądu Pracy (Bundesarbeitsgericht, dalej: „BAG”) z 7 maja 2019 roku (1 ABR 53/17, NZA 2019, 1218). Najogólniej rzecz ujmując, w sprawach tych chodziło o to, że rada zakładowa domagała się wglądu w wykazy wynagrodzeń brutto zawierające dane osobowe konkretnych pracowników, takie jak imiona, nazwiska, numery identyfikacyjne, wiek itp., tłumacząc, że tylko w ten sposób jest w stanie ustalić, według jakich zasad pracodawca przyznaje podwyżki lub premie albo czy przestrzega ustaw, układów zbiorowych pracy lub zasady równego traktowania w tym obszarze, a pracodawca odmawiał udostępnienia takich list płac, powołując się między innymi na ochronę danych osobowych.

Sądy pracy przyjęly we wskazanych wyżej orzeczeniach, że przewidziane w $\$ 80$ ust. 2 BetrVG prawo wglądu komitetu zakładowego lub komitetu utworzonego zgodnie $\mathrm{z} \$ 28$ BetrVG w wykazy wynagrodzeń brutto nie ogranicza się do anonimowych list. Przywołały w tym kontekście cel $\$ 80$ ust. 2 BetrVG, ściśle związany z realizacją przysługujących radzie zadań (przepis ten wprost przewiduje, że wgląd w listy płac brutto ma być konieczny do wykonywania zadań rady). Cel prawa wglądu w wykazy wynagrodzeń brutto nie mógłby zostać osiągnięty, gdyby rada otrzymywała informacje o wynagrodzeniach bez danych pracowników (LAG Sachsen-Anhalt, 18 grudnia 2018 4 TaBV 19/17, NZA-RR 2019, 256). Tylko listy płac brutto z danymi osobowymi pracowników (imiona, nazwiska, numery identyfikacyjne na wypadek identycznych imion i nazwisk, daty urodzenia) pozwalają ustalić, którzy pracownicy otrzymują dane składniki wynagrodzenia, a także w jakiej wysokości. Dokonanie takich ustaleń jest niekiedy konieczne, aby rada zakładowa mogła wykonać przysługujące jej zadania. Dotyczy to chociażby sprawdzenia, czy poszczególne składniki wynagrodzenia są wypłacane przez pracodawcę zgodnie $z$ ustawami lub układami zbiorowymi pracy (w ramach przewidzianego w $\$ 80$ ust. 1 pkt 1 BetrVG prawa do kontroli przestrzegania wymienionych w tym przepisie aktów) i czy przyjęta w tym obszarze praktyka pozostaje w zgodzie z zasadą równego traktowania (w kontekście spoczywającego na radzie zakładowej zadania kontrolowania przestrzegania tej zasady $-\$ 75 \mathrm{BetrVG}$ ). Na podobne uzasadnienie zwraca się uwagę w literaturze przedmiotu (Kania 2020, $₫ 80$ BetrVG, nr 25). Poza tym wskazuje się, że rada powinna mieć też możliwość podjęcia inicjatywy w celu osiągnięcia w zakładzie sprawiedliwości płacowej (Fitting 2020, §80 BetrVG, nr 73).

Prawo wglądu w listy płac brutto nie jest uzależnione od zgody pracownika, którego sfera indywidualna musi w tym względzie ustąpić. W przeciwnym razie rada zakładowa nie mogłaby realizować swoich zadań (Fitting 2020, $\$ 80$ BetrVG, nr 77; Kania 2020, $\$ 80$ BetrVG, nr 27 i przywołane przez autorów orzecznictwo).

W ocenie judykatury prawu wglądu przedstawicielstwa pracowniczego w listy płac brutto zawierające informacje o konkretnych pracownikach nie sprzeciwia się ani RODO, ani niemiecka ustawa o ochronie danych osobowych (Bundesdatenschutzgesetz, dalej: „BDSG”). Realizacja tego prawa prowadzi wprawdzie do przetwarzania danych osobowych w rozumieniu art. 4 pkt 2 RODO, ale jest ono dopuszczalne. 
RODO przewiduje w art. 6 ust. 1 lit. c, że przetwarzanie jest zgodne z prawem, gdy jest ono niezbędne do wypełnienia obowiązku prawnego ciążącego na administratorze. Artykuł 6 ust. 3 RODO wymaga w przypadku przetwarzania na podstawie ust. 1 lit. c określenia celu tego przetwarzania w prawie Unii lub w prawie państwa członkowskiego, któremu podlega administrator. Ustawodawca niemiecki wskazał ten cel $\mathrm{w} \$ 26$ BDSG, dotyczącym przetwarzania danych osobowych do celów związanych ze stosunkiem zatrudnienia. $\$ 26$ ust. 1 BDSG wprost stanowi, że dane osobowe zatrudnionych mogą być przetwarzane do celów związanych ze stosunkiem zatrudnienia, jeżeli jest to niezbędne między innymi do wykonywania lub wypełniania praw i obowiązków przedstawicielstwa zatrudnionych. W przywołanym wyżej orzecznictwie ocenia się, że w przypadku prawa wglądu w listy płac brutto wyrażonego $\mathrm{w} \$ 80$ ust. 2 BetrVG wymagania te są spełnione. Jeśli bowiem rada zakładowa ma prawo wglądu w określone dokumenty (spełniona jest przesłanka niezbędności), występuje konieczność przetwarzania związanych z tym danych zgodnie $z \$ 26$ ust. 1 BDSG. Nie jest wówczas potrzebne wyważanie interesów informacyjnych rady zakładowej ani interesów pracodawcy i/lub pracowników (odmiennie Wybitul, Böhm 2019, s. 260). Z punktu widzenia ochrony danych niezbędnego wyważenia interesów dokonał sam ustawodawca, uznając dopuszczalność przetwarzania danych w celu wypełnienia ustawowego obowiązku (BAG, 7 maja 2019 - 1 ABR 53/17, NZA 2019, 1218). Nie bez znaczenia jest w tym kontekście sposób ukształtowania prawa wglądu w listy płac brutto. $Z$ jednej strony prawo to przysługuje tylko wówczas, gdy jest ono niezbędne do wykonywania obowiązków rady zakładowej. Z drugiej strony sprowadza się jedynie do „wglądu” w listy, dotyczy tylko wynagrodzeń brutto (co ma przeciwdziałać ujawnianiu informacji o sytuacji osobistej pracowników związanej na przykład z zajęciem wynagrodzenia) i przysługuje ograniczonemu kręgowi uprawnionych, którzy mają obowiązek zachować uzyskane informacje w tajemnicy (szerzej Fitting 2020, \$80, nr 71-72 i 76; Kania 2020, \$80, nr 27-30 i przywołane tam orzecznictwo).

Norma zawarta w $\$ 26$ ust. 1 BDSG stanowi bardziej szczegółowy przepis w rozumieniu art. 88 RODO (Franzen 2019, \$ 26 BDSG, nr 2), który stwarza państwom członkowskim możliwość zawarcia w swoich przepisach lub w porozumieniach zbiorowych bardziej szczegółowych regulacji mających zapewnić ochronę praw i wolności w przypadku przetwarzania danych osobowych pracowników w związku z zatrudnieniem, w szczególności do wymienionych w niniejszym artykule celów, w tym zbiorowego wykonywania praw.

Na podstawie przedstawionej argumentacji w przywołanym wyżej orzecznictwie uznaje się, że dopuszczalność przetwarzania danych w związku z realizacją prawa wglądu w listy płac brutto na podstawie $\$ 80$ ust. 2 BetrVG, znajdująca oparcie w $\$ 26$ BDSG, nie budzi zastrzeżeń w świetle prawa Unii Europejskiej (BAG, 7 maja 2019 roku - 1 ABR 53/17, NZA 2019, 1218). Warto jednak zauważyć, że w niemieckiej literaturze przedmiotu pojawiają się także głosy, iż z powodu wejścia w życie RODO 
w przyszłości może dochodzić do ograniczeń lub modyfikacji (na przykład anonimizacji czy pseudonimizacji danych) przy udzielaniu informacji radzie zakładowej (Lücke 2019, s. 659; por. Wybitul, Böhm 2019, s. 260).

\section{Zakończenie}

Wyrażany niemalże powszechnie w doktrynie i judykaturze pogląd o braku obowiązku ujawniania związkom zawodowym, na ich wniosek, informacji o wysokości wynagrodzenia za pracę, oparty zasadniczo na podjętej przez Sąd Najwyższy uchwale z 1993 roku, budzi uzasadnione wątpliwości w aspekcie zarówno prawnym, jak i aksjologicznym. Dotychczasowe rozważania upoważniają do konstatacji, że na pracodawcy ciąży jednak taki obowiązek, a jego realizacja nie wymaga zgody pracownika. Udostępnianie związkom takich informacji pozostaje w zgodzie z polskimi przepisami o ochronie dóbr osobistych. Nie narusza też przepisów RODO, o czym zdaje się przekonywać orzecznictwo sądów niemieckich dotyczące udostępniania radzie zakładowej informacji o wynagrodzeniach pracowników.

Wieloletnia tradycja postrzegania regulacji prawnej i jej wykładni w określony sposób jest niezwykle trudna do przełamania, nawet przy istnieniu istotnych argumentów prawnych przemawiających przeciwko stanowisku Sądu Najwyższego zajętemu w uchwale z 1993 roku. Mając to na uwadze, można widzieć potrzebę interwencji ustawodawcy, która jednoznacznie przesądziłaby o istnieniu po stronie pracodawcy obowiązku informacyjnego w przedmiocie ujawniania związkom zawodowym informacji o wysokości wynagrodzeń pracowników. Wskazane byłoby przy tym wprowadzenie regulacji osłonowej, której dziś brakuje. Ustawa powinna określać zasady i warunki ujawniania związkom zawodowym informacji o wynagrodzeniach pracowników, gwarancje zachowania poufności takich informacji (na przykład przez objęcie ich tajemnicą przedsiębiorstwa) czy chociażby sankcje z tytułu naruszenia poufności informacji, o których mowa. Taka osłonowa regulacja mogłaby stworzyć gwarancje, że trzy wartości, które pozostają względem siebie w konflikcie, to jest prawo pracownika do prywatności, prawo związku zawodowego do pozyskiwania informacji i zasada równego traktowania pracowników w zakresie wynagradzania za pracę, byłyby odpowiednio wyważone.

Problem jednak w tym, że u większości pracodawców w Polsce związki zawodowe nie działają. Należałoby rozważyć, jakie dodatkowe instrumenty systemowej kontroli przestrzegania zasady równego traktowania pracowników w zakresie wynagradzania za pracę należałoby przewidzieć w zakładach pracy, które nie są objęte działalnością związku zawodowego. Jest to jedno $\mathrm{z}$ istotniejszych wyzwań stojących przed nauką prawa pracy. 


\section{Bibliografia}

Baran K.W. (2010) Zbiorowe prawo pracy. Komentarz, Warszawa.

Baran K.W. (2019) Prawo związków zawodowych do informacji po nowelizacji ustawy związkowej, „Monitor Prawa Pracy”, nr 1.

Cudowski B. (2013) Ujawnienie wynagrodzenia przez pracownika jako przyczyna rozwiąania stosunku pracy [w:] B. Cudowski, J. Iwulski (red.), Z aktualnych zagadnień prawa pracy i zabezpieczenia społecznego. Księga Jubileuszowa Profesora Waleriana Sanetry, Białystok.

Derlacz-Wawrowska M. (2013) Prawo związków zawodowych do informacji. Stan obecny i propozycje zmian [w:] B. Balcerzak-Paradowska (red.), Praca i polityka społeczna. Współczesne tendencje $i$ wyzwania, Warszawa.

Derlacz-Wawrowska M. (2015) Ochrona informacji poufnych pracodawcy $w$ indywidualnym i zbiorowym prawie pracy, Warszawa.

Drozd A. (2012) Uprawnienie związku zawodowego do informacji o wynagrodzeniu pracownika, „Monitor Prawa Pracy”, nr 8.

Fitting K. (2020) Betriebsverfasssungsgesetz. Handkommentar, München, $₫ 80$ BetrVG.

Franzen M. (2019) [w:] Erfurter Kommentar zum Arbeitsrecht, München, $\$ 26$ BDSG.

Gersdorf M. (2014) [w:] M. Gersdorf, K. Rączka, M. Raczkowski, Komentarz do kodeksu pracy, Warszawa.

Hromadka W., Maschmann F. (2017) Arbeitsrecht, II: Kollektivarbeitsrecht + Arbeitsstreitigkeiten, Berlin-Heidelberg.

Junker A. (2019) Grundkurs Arbeitsrecht, München.

Kamińska J., Rozbicka-Kamińska M. (2012) Ustawa o dostępie do informacji publicznej. Komentarz, Warszawa.

Kania T. (2020) [w:] Erfurter Kommentar zum Arbeitsrecht, München, $₫ 80$ BetrVG.

Książek D. (2019) Uprawnienia związków zawodowych [w:] K.W. Baran (red.), Zbiorowe prawo zatrudnienia. Komentarz, Warszawa.

Kulesza E. (2017) D. Dörre-Kolasa (red.), Prawo związków zawodowych do danych pracowników przetwarzanych przez pracodawcę. Przetwarzanie danych osobowych w procesie współdziałania pracodawcy ze zwiazkami zawodowymi w sprawach indywidualnych [w:] D. Dörre-Kolasa (red.), Ochrona danych osobowych pracowników w świetle rozporządzenia Parlamentu Europejskiego $i$ Rady (UE) 2016/679, Warszawa.

Lücke O. (2019) Die Betriebsverfassung in Zeiten der DS-GVO. „Bermuda-Dreieck” zwischen Arbeitgeber, Betriebsräten und Datenschutzbeauftragten!?, „Neue Zeitschrift für Arbeitsrecht”, Vol. 658.

Niezbecka E. (1992) Ujawnianie wysokości wynagrodzeń pracowników a ochrona dóbr osobistych osób fizycznych, „Praca i Zabezpieczenie Społeczne”, nr 8.

Piątkowski J. (2008) Uprawnienia zakładowej organizacji związkowej, Toruń.

Piątkowski J. (2017) Aksjologiczne i normatywne podstawy prawa stosunku pracy, Toruń.

Safjan M. (2002) Prawo do prywatności i ochrona dóbr osobistych w społeczeństwie informatycznym, „Państwo i Prawo”, z. 6.

Szewczyk H. (2007) Ochrona dóbr osobistych w zatrudnieniu, Warszawa. 
Walczak K. (2015) Praktyczne problemy z interpretacją zasady niedyskryminacji w wynagradzaniu, „Annales Universitatis Mariae Curie-Skłodowska”, sectio G (Ius), Vol 62, No 2.

Walczak K. (2017) Informacja dotyczaca wysokości wynagrodzenia pracownika. Tajemnica pracodawcy czy tajemnica pracownika? [w:] M. Szabłowska-Juckiewicz, B. Rutkowska, A. Napiórkowska (red.), Tendencje rozwojowe indywidualnego i zbiorowego prawa pracy. Ksiega Jubileuszowa Profesora Grzegorza Goździewicza, Torun.

Włodarczyk M. (2001) Jeszcze w sprawie dostępu związku zawodowego do informacji o wynagrodzeniach pracowników w kontekście ustawy o ochronie danych osobowych [w:]

B.M. Ćwiertniak (red.), Prawo pracy, Opole.

Włodarczyk M. (2012) Prawo związków zawodowych do informacji o pracownikach [w:] T. Wyka, A. Nerka (red.), Obrona danych osobowych podmiotów objętych prawem pracy i prawem ubezpieczeń społecznych. Stan obecny i perspektywy zmian, Warszawa.

Włodarczyk M. (2014) [w:] K.W. Baran (red.), System prawa pracy, t. 5: Zbiorowe prawo pracy, Warszawa.

Wujczyk M. (2019) Nowe regulacje funkcjonowania związków zawodowych - wybrane zagadnienia, „Studia z Zakresu Prawa Pracy i Polityki Społecznej”, nr 26.

Wybitul T., Böhm W.-T. (2019) LAG Sachsen-Anhalt: Erweitertes Einsichtnahmerecht des Betriebsrats in nicht anonymisierte Gehaltslisten (Anmerkung), „Neue Zeitschrift für Arbeitsrecht - Rechtsprechungsreport", Vol. 259.

\section{Orzecznictwo}

Uchwała pełnego składu Izby Administracyjnej, Pracy i Ubezpieczeń Społecznych z dnia 11 marca 1993 roku, I PZP 68/92, OSNC 1993, nr 9, poz. 140.

Uchwała składu siedmiu sędziów Sądu Najwyższego z dnia 16 lipca 1993 roku, I PZP 28/93, OSNC 1994, nr 1, poz. 2.

Wyrok Sądu Najwyższego z dnia 24 października 2012 roku, I PK 151/12, OSNP 2013, nr 17-18, poz. 205.

Wyrok Sądu Apelacyjnego w Białymstoku z dnia 25 czerwca 2014 roku, III AUa 2078/13, LEX nr 1493722.

Wyrok Naczelnego Sądu Administracyjnego z dnia 2 grudnia 2015 roku, II OSK 847/14, LEX nr 2000035.

Wyrok Trybunału Konstytucyjnego z dnia 26 kwietnia 2018 roku, K 6/15, Dz.U. 2018, poz. 830. LAG (Landesarbeitsgericht) Sachsen-Anhalt, 18 grudnia 2018 roku - 4 TaBV 19/17, „Neue Zeitschrift für Arbeitsrecht - Rechtsprechungsreport" 2019, 256.

BAG (Bundesarbeitsgericht), 7 maja 2019 roku - 1 ABR 53/17, „Neue Zeitschrift für Arbeitsrecht” 2019, 1218.

LAG (Landesarbeitsgericht) Mecklenburg-Vorpommern, 15 maja 2019 roku - 3 TaBV 10/18. 


\section{Akty prawa}

Konstytucja Rzeczypospolitej Polskiej z dnia 2 kwietnia 1997 roku, Dz.U. 1997, nr 78, poz. 483 ze zm.

Ustawa z dnia 26 czerwca 1974 roku - Kodeks pracy, Dz.U. 2020, poz. 1320 tekst jedn.

Ustawa z dnia 31 lipca 1981 roku o wynagrodzeniu osób zajmujących kierownicze stanowiska państwowe, Dz.U. 2020, poz. 1637 tekst jedn.

Ustawa z dnia 23 maja 1991 roku o związkach zawodowych, Dz.U. 2019, poz. 263 tekst jedn.

Ustawa z dnia 3 marca 2000 roku o wynagradzaniu osób kierujących niektórymi podmiotami prawnymi, Dz.U. 2019, poz. 2136 tekst jedn.

Ustawa z dnia 6 września 2001 roku o dostępie do informacji publicznej, Dz.U. 2020, poz. 2176 tekst jedn.

Ustawa z dnia 13 kwietnia 2007 roku o Państwowej Inspekcji Pracy, Dz.U. 2019, poz. 1251 tekst jedn.

Rozporządzenie Parlamentu Europejskiego i Rady (UE) nr 2016/679 z dnia 27 kwietnia 2016 roku w sprawie ochrony osób fizycznych w związku z przetwarzaniem danych osobowych i w sprawie swobodnego przepływu takich danych oraz uchylenia dyrektywy 95/46/WE (ogólne rozporządzenie o ochronie danych), Dz.Urz. UE L 2016, nr 119/1.

Ustawa z dnia 10 maja 2018 roku o ochronie danych osobowych, Dz.U. 2019, poz. 1781 tekst jedn. 